CIRR XXIII (78) 2017, 19-34

ISSN 1848-5782

UDC 327/5 10:4-7 11

DOI 10.1515/cirr-2017-0005

\title{
China-CEEC Cooperation: China's Building of a New Type of International Relations
}

Liu Zuokui

\section{Abstract}

The article analyzes how the $16+1$ Cooperation promotes the Chinese new type of international relations from four perspectives: firstly, the "16+1 Cooperation" insists on not rejecting third parties and promotes the idea of open and inclusive international cooperation; Secondly, the cooperation framework adheres to the principle of mutually-beneficial and win-win cooperation, and proposes to wisely handle differences and divergences; Thirdly, this framework never engages in zero-sum games, instead, it fully respects and closely watches the core interests and major concerns of the relevant parties; Fourthly, it is committed to creating a cooperative platform through consultation, to meet the interests of all. The article also makes an analysis of the challenges facing $16+1$ Cooperation and gives some suggestions.

\section{KEY WORDS:}

$16+1$ Cooperation Framework, new type of international relations, challenges ahead, policy suggestions 


\title{
Forward
}

When Chinese President Xi Jinping visited Russia on 23 March 2013, he made a keynote speech at Moscow State institute of International Relations titled: "Keeping with the trend of the times, and promoting the world peace and development" (Xinhuanet 2013). During his speech, Xi proposed to build a new type of international relations with a focus on mutually-beneficial and win-win cooperation. He stated that:

\begin{abstract}
"The world tide is moving forward with unstoppable might. Those moving with the current will see prosperity, while those going against it will plunge to their doom; therefore we should abandon the colonial expansion or the zero-sum Cold War mentality and keep up with the trend of the times. All countries should jointly promote to establish new-typed international relations centering around the win-win cooperation. Moreover, all peoples of the world should work together to safeguard the world peace and push forward the common development" (Xinhuanet 2013).
\end{abstract}

His proposal in handling international relations has been closely followed by the international community, with wide interest in checking whether the initiative will be implemented in China's diplomacy.

From 4 to 6 November 2016, Premier Li Keqiang paid a visit to Latvia and attended the 5th Meeting of the Heads of Government of China and 16 Central and Eastern European countries (the CEECs). At the "16+1 Economic and Trade Forum", Li stressed that ever since the "16+1 Cooperation" mechanism was established five years ago, it has become increasingly mature and gathered many valuable and sustainable experiences, namely: consultation on the basis of equality; mutual respect and mutual support; mutually-beneficial and winwin cooperation; openness and inclusiveness; joint development and interests created and shared by all (People 2016). The meeting showcases China's practice of building a new pattern of international relations based on mutual benefit and win-win cooperation, and creating new dynamics and a new vision for the "16+1 Cooperation". 
Under the initiative of the Chinese government, China and the 16 CEECs jointly launched the "16+1 Cooperation" framework in 2012. Ever since then, China has been actively carrying out " $16+1$ Cooperation" based on the principle of openness and inclusiveness, mutual benefit and win-win cooperation, and has achieved fruitful results. The "16+1 Cooperation" framework, so to speak, is China's latest attempt to construct the aforementioned new-type of international relations.

\section{How "16+1 Cooperation" promotes a new type of international relations}

There are four different ways in which "16+1 Cooperation" promotes a new type of international relations. Firstly, the " $16+1$ Cooperation" insists on not rejecting third parties and promotes the idea of open and inclusive international cooperation.

It has been 5 years since the "16+1 Cooperation" framework was established in 2012. So far it has attracted attention from the international community and the interest of countries and organizations outside the framework, with the intention of joining. Greece, Austria, the European Bank for Reconstruction and Development, Belarus and Switzerland all showed strong interest in participation at different stages.

The representatives of EU institutions were all invited to attend the Annual Meeting of Heads of Government of China and CEECs. The EU's attitude, likewise, has also gone through a positive change from an initial period of suspicion to the present willingness to collaborate with China. Moreover, the EU expects the "16+1 Cooperation" to be the critical platform to boost China-EU cooperation. At the $3^{\text {rd }}$ Meeting of Heads of Government of China and CEECs, held in Belgrade, Serbia, Greece was invited to attend the meeting and worked together with CEECs including Macedonia, Hungary and Serbia to build the China-Europe Land-Sea Express Route. Accordingly, Greece became the first beneficiary of increased cooperation with China, outside the " $16+1$ Cooperation" framework. At the $4^{\text {th }}$ Meeting 
of Heads of Government of China and CEECs, held in Suzhou, China, Austria and the European Bank for Reconstruction and Development were also invited as third parties. Austria is a Central European country that maintains a close relationship with the Višegrad Group and enjoys influential status in the CEE region. More importantly, Austria is showing enthusiasm towards joining the "16+1 Cooperation" framework. As an internationally-recognized, development-oriented financial institution, the European Bank for Reconstruction and Development engages in a wide range of business in the CEE region. The participation of the European Bank for Reconstruction and Development has provided more opportunities for China-CEECs cooperation in the financial realm. In addition, Belarus and Switzerland attended the $5^{\text {th }}$ Meeting of Heads of Government of China and CEECs held in Riga, Latvia, as observers. Belarus has always been an important node of the Silk Road on land, linking Russia and the CEECs. Switzerland also maintains an extensive presence as a stakeholder in the CEE region. Ever since the CEECs were admitted into the European Union in 2004, Switzerland has sped up its market accession eastwards, with a great number of enterprises investing comprehensively in the CEE region. In order to safeguard its strategic investments and tap into a huge market of 75 million customers, for over a decade from 2004 to 2014, Switzerland started to finance over 300 cooperative projects in the CEE region. These projects covered economy, tourism, health, energy, and more, with a total of 1.3 trillion Swiss francs. The engagement of Switzerland has undoubtedly broadened the scope of the "16+1 Cooperation" framework.

The process of " $16+1$ Cooperation" has suggested that the initiative proposed by the Chinese government is not a closed-off and cyclic system. Instead, it is an open, inclusive and mutually beneficial cooperative framework that welcomes and supports all willing parties to join in and expand cooperation.

The second way in which "16+1 Cooperation" is promoting a new type of international relations is that the cooperation framework adheres to the principle of mutually-beneficial and win-win cooperation, and proposes to wisely handle differences and divergences.

There exist great differences among the 16 CEE countries, with each country having particular demands. The CEE region is not a homogeneous 
region either. I have participated in a great many conferences and seminars hosted by CEECs such as the international seminar on energy cooperation among the three Baltic countries (Estonia, Latvia, Lithuania), held in Latvia on 17 October 2016. I used to think that the Baltic countries are relatively alike in terms of national conditions. It was not until the seminar that I started to realize that each attending representative of the abovementioned countries was not there to seek consensus. Instead, they all made use of precious time to illustrate why their country (and their energy policy in particular) is different from the other two. In fact, this reflected the common mindset of CEECs, that the aim of the symposium is to handle differences and divergences through communication and consultation.

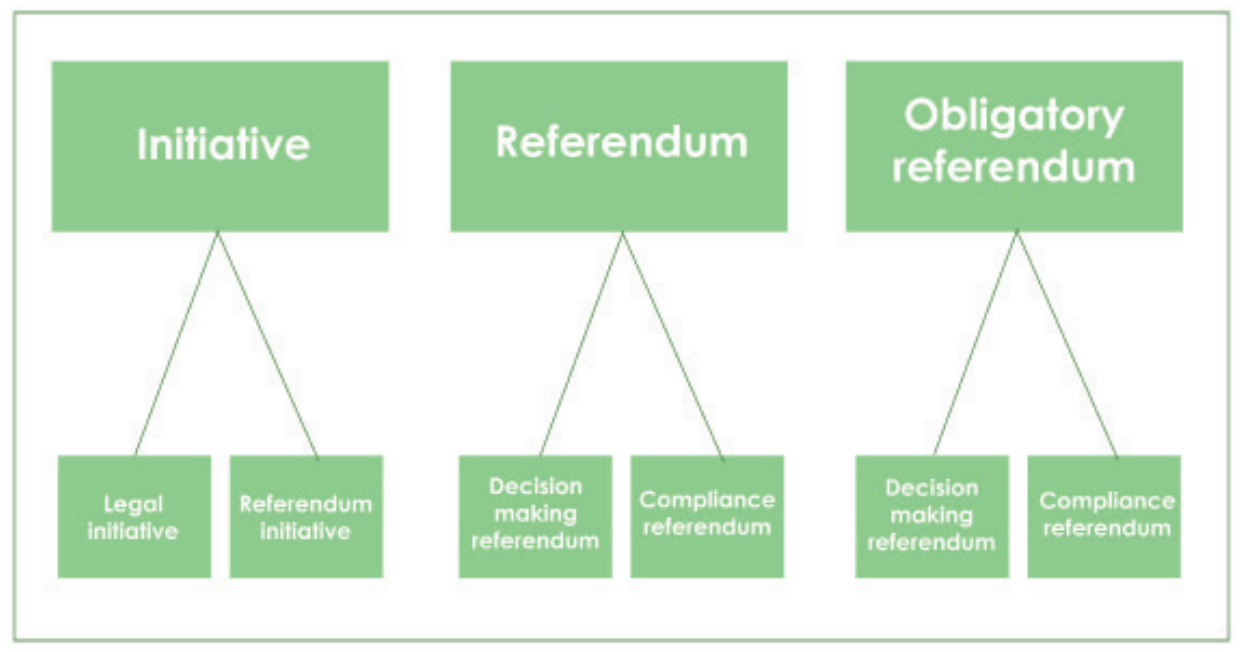

The current diversity of CEECs in terms of national conditions, domestic politics and foreign policies is the direct result of European integration at different stages. To go into detail, some CEECs are EU member states while others are not; some are Euro-zone countries while others are nonEuro countries. As an actor who is deeply involved in the CEE region, the EU has contributed tremendously to the accession and integration of CEECs to the EU, but such efforts also led to the unbalanced development of CEECs. Thus, it is reasonable to conclude that the contradictions and differences among CEECs are common and almost impossible to reconcile. The EU has failed to do so and is showing signs of expansion fatigue. 
The "16+1 Cooperation" framework has wisely and flexibly handled the differences among CEECs. Specifically, the framework focuses on the win-win cooperation and suggests participating countries should seek common ground while minimizing differences, learning lessons and sharing each other's successes in the spirit of mutual respect and understanding. A case in point is that, so far, CEECs have put forward many proposals aiming to integrate with the "16+1 Cooperation" framework and the "Belt and Road" Initiative such as the "Danube Strategy", the cooperative projects in the Adriatic, Black and Baltic Sea regions, the "Amber Road", etc. Each one of these initiatives has pros and cons. The "Danube Strategy" exploits the estuary of the Danube River, therefore receiving a lot of attention from the Balkan states. The Baltic countries, on the other hand, are more concerned with the "Amber Road" Initiative which gives rise to trade and inter-connectivity among those states. The cooperative projects in the Adriatic, Black and Baltic Sea regions focus on regional integration and cooperation in the fields of energy, communication and transportation, among CEECs that are members of the EU. The different initiatives are indeed exclusive to a certain degree, as the cooperative projects in the Adriatic, Black and Baltic Sea regions mainly involve CEECs that are members of the EU while the western Balkans (except Croatia) are excluded. The "Amber Road" was mainly proposed by the Baltic countries and Southeastern Europe barely has the opportunity to get involved. Based on this situation, the Chinese government has been actively promoting synergy within the " $16+1$ Cooperation" framework and the above-mentioned initiatives, by proposing infrastructure and logistics cooperation in the Adriatic, Black and Baltic Sea regions. The project has integrated all the merits and positives of existing initiatives, offsetting their weaknesses. To begin with, it is more inclusive than the cooperative projects in the Adriatic, Black and Baltic Sea regions as it involves CEECs that are non-EU members. Secondly, it is more comprehensive than the "Danube Strategy" as it comprises logistics and infrastructure cooperation including ports, wharfs, and so on. Moreover, it is more pluralistic than the "Amber Road" initiative as it is not limited to regional trade and interconnectivity.

The "16+1 Cooperation" framework has pioneered a new model of international relations in the new era of globalization which emphasizes mutual respect, harmonious coexistence, mutually-beneficial and win- 
win cooperation between China and CEECs of different social systems, cultural traditions and stages of development. China's flexible and pragmatic policies are in line with the vision of CEECs that advocate independent choice of their development path. The cooperation based on the mutual learning and understanding between China and 16 CEECS is a new classic in the field of international relations.

The third way in which " $16+1$ Cooperation" promotes a new form of international relations is that it never engages in a zero-sum game. Instead, it fully respects and closely watches the core interests and major concerns of the relevant parties.

The "16+1 Cooperation" framework initiated by China neither contests the interests of others, nor engages in a zero-sum game. Instead, it takes the core interests and major concerns of all parties into full consideration. This can be clearly seen from China's deeds in handling relations between "16+1 Cooperation" and the EU. The EU has always been suspicious of China's motives in proposing "16+1 Cooperation", worried that China is adopting a "divide-and-rule" policy which will exert negative influence upon solidarity within the EU and the efficiency of related EU policies. The EU institutions and Germany, for instance, have voiced their concerns over "16+1 Cooperation" on many occasions. In response, China has fully acknowledged the EU's influence as a peaceful power and supports EU's unity and self-reliance, especially at a time when the EU is faced with multiple crises such as the financial crisis, refugee crisis and regional conflicts, etc. Moreover, China is committed to promoting balanced development within EU and EU-China cooperation through "16+1 Cooperation", rather than playing zero-sum games.

The "16+1 Cooperation" framework promotes multiple synergies between China and Europe, which has indeed reflected China's respect and concern about the EU's core interests. Here I would like to elaborate on the synergy between China and Europe in the infrastructure sector by listing three examples. The first example is that before the $5^{\text {th }}$ Meeting of Heads of Government of China and CEECs, there were plenty of reports about China's possible acquisition of the Baltic port. However, China pays more attention to the Baltic railway which is a mutually-beneficial project under the "16+1 Cooperation" framework and China-EU partnerships. The Baltic 
railway is an important project funded by the EU that starts from Helsinki, via Estonia, Latvia, Lithuania, and Warsaw, to Berlin. Chinese enterprises have always been keen on the project and hope to introduce Chinese techniques and experiences of building high-speed railways to the Baltic region, so as to enhance the connectivity of the EU as a whole. The second example is that China is now actively pushing forward the construction of the China-Europe Land-Sea Express Route, the Hungary-Serbia high-speed railway in particular. The Hungary-Serbia high-speed railway connects the north to the south and thus advances north-south connectivity, which is in accord with Pan-European transport corridors and has largely promoted the pragmatic cooperation between China and Europe. The third example is that of Chinese enterprises vigorously promoting cooperation with the Klaipeda port of Lithuania. The Klaipeda port deals with freight transport in the construction of the Silk Road Economic Belt, and is the perfect convergence of freight that departs from China and arrives at North Europe and West Europe via Central Asia, Russia, Belarus, and Klaipeda of Lithuania. According to the Development Plan of CR Express Construction 2016-2020, issued by the National Development and Reform Committee, the construction of the China-Europe railway transport corridor, with transportation hubs, should be completed by 2020 so as to promote China-Europe freight transport and trade to the greatest extent. Many CEECs, including Lithuania, will play the role of a transportation hub in the construction of the corridor. In a nutshell, "16+1 Cooperation" has truly boosted China-Europe cooperation and will become a new driving force for furthering that cooperation.

The fourth and final way in which " $16+1$ Cooperation" is emblematic of a new type of international relations is how it is committed to creating a cooperative platform through consultation, to meet the interests of all.

In today's world, international relations are normally shaped by multiple, multilateral platforms such as the G20, BRICS, South-South cooperation, etc. They are more like mechanisms playing the role of functional platforms. Chinese foreign policy, in recent years, has increasingly given rise to platform building and participation, through which China expects to create new-types of initiatives for cooperation, and explore common benefits. More importantly, China seeks to promote a new model of international relations. 
The "16+1 Cooperation" framework has shown how such multilateral platforms not only integrate a variety of resources, but also enjoy great popularity and a large voice in crucial global affairs. The platform, which gathers all sources of information and provides intellectual support, is established for all parties to exchange views, brainstorm new ideas, tap the potential for cooperation, and enrich practical cooperation. Under the general " $16+1$ Cooperation" platform, there are a range of sub-platforms that are more specialized and centralized, as detailed in Table 1.

Table 1: Coordination mechanisms or platforms established or in-progress under the "16+1 Cooperation" framework

\begin{tabular}{|c|c|c|c|}
\hline $\begin{array}{l}\text { Coordination } \\
\text { Mechanism or Platform }\end{array}$ & Site of Secretariat & Organizer & Progress \\
\hline $\begin{array}{l}\text { 16+1 Agency for } \\
\text { Tourism Promotion } \\
\text { and Association of } \\
\text { Enterprises }\end{array}$ & Hungary & $\begin{array}{l}\text { Hungary Travel } \\
\text { Company }\end{array}$ & Established \\
\hline $\begin{array}{l}16+1 \text { Association } \\
\text { of Colleges and } \\
\text { Universities }\end{array}$ & & $\begin{array}{l}\text { Ministries of Education } \\
\text { of the } 16 \text { CEECs }\end{array}$ & Established \\
\hline $\begin{array}{l}16+1 \text { Contact } \\
\text { Mechanism for } \\
\text { Investment Promotion }\end{array}$ & Poland & $\begin{array}{l}\text { Polish Information and } \\
\text { Foreign Investment } \\
\text { Agency }\end{array}$ & Established \\
\hline $16+1$ Commercial Union & $\begin{array}{l}\text { Poland (executive } \\
\text { agency), China } \\
\text { (Secretariat) }\end{array}$ & $\begin{array}{l}\text { China Council for } \\
\text { the Promotion of } \\
\text { International Trade }\end{array}$ & Established \\
\hline $\begin{array}{l}\text { 16+1 Association of } \\
\text { Governors }\end{array}$ & $\begin{array}{l}\text { The Czech } \\
\text { Republic }\end{array}$ & Czech Interior Ministry & Established \\
\hline $\begin{array}{l}16+1 \text { Association for } \\
\text { Agriculture Promotion }\end{array}$ & Bulgaria & $\begin{array}{l}\text { Bulgarian Ministry of } \\
\text { Agriculture and Food }\end{array}$ & Established \\
\hline $\begin{array}{l}\text { 16+1 Technology } \\
\text { Transfer Center }\end{array}$ & Slovakia & $\begin{array}{l}\text { Science and } \\
\text { Information Center of } \\
\text { Slovakia }\end{array}$ & Established \\
\hline $\begin{array}{l}16+1 \text { Thinks Tanks } \\
\text { Exchange and } \\
\text { Cooperation Network }\end{array}$ & China & $\begin{array}{l}\text { Chinese Academy of } \\
\text { Social Sciences }\end{array}$ & Established \\
\hline
\end{tabular}




\begin{tabular}{|c|c|c|c|}
\hline $\begin{array}{l}\text { Coordination } \\
\text { Mechanism or Platform }\end{array}$ & Site of Secretariat & Organizer & Progress \\
\hline $\begin{array}{l}\text { 16+1 Association } \\
\text { for Transportation } \\
\text { Infrastructure } \\
\text { Cooperation }\end{array}$ & Serbia & $\begin{array}{l}\text { Serbian Ministry of } \\
\text { Transport }\end{array}$ & In progress \\
\hline $\begin{array}{l}\text { 16+1 Association for } \\
\text { Logistics Cooperation }\end{array}$ & Latvia & $\begin{array}{l}\text { Latvian Ministry of } \\
\text { Transport }\end{array}$ & Established \\
\hline $\begin{array}{l}16+1 \text { Association for } \\
\text { Forestry Cooperation }\end{array}$ & Slovenia & $\begin{array}{l}\text { Slovenian Ministry of } \\
\text { Agriculture, Forestry } \\
\text { and Food }\end{array}$ & Established \\
\hline $\begin{array}{l}\text { 16+1 Association for } \\
\text { Health Cooperation }\end{array}$ & To be determined & To be determined & In progress \\
\hline $\begin{array}{l}16+1 \text { Association for } \\
\text { Arts Cooperation }\end{array}$ & To be determined & To be determined & In progress \\
\hline $\begin{array}{l}16+1 \text { Association for } \\
\text { Customs Cooperation }\end{array}$ & To be determined & To be determined & In progress \\
\hline $\begin{array}{l}16+1 \text { Association for } \\
\text { Energy Cooperation }\end{array}$ & Romania & To be determined & In progress \\
\hline $\begin{array}{l}16+1 \text { Association for } \\
\text { Maritime Cooperation }\end{array}$ & Poland & To be determined & In progress \\
\hline $\begin{array}{l}\text { 16+1 Coordination } \\
\text { Center for Cultural } \\
\text { Cooperation }\end{array}$ & Macedonia & To be determined & In progress \\
\hline
\end{tabular}

As a matter of fact, "16+1 Cooperation" has been well-received in the past 5 years. In spite of ups and downs, most CEECs started to take a proactive attitude towards the cooperation framework soon after realizing its positives. A Baltic diplomat once told me that the Baltic countries are more inclined to join the cooperation platform initiated by North European countries rather than the "16+1", because the Baltic states are quite different from most CEECs in terms of history, national condition, comprehensive capability, domestic policy and diplomacy. In response to this, I said that differences never prevail over collaboration, nor do they prevent a country from joining a cooperative platform. The BRICs are 
obviously more diversified in terms of social and economic systems, size of the country, race and color. Still, BRICs cooperation develops robustly. The "16+1 Cooperation" mechanism has offered a new window and a rare opportunity for collaboration between China and CEECs. It turned out that the Baltic diplomat was convinced by my views.

In a word, China's initiatives regarding international relations has revealed a Chinese mindset of openness, inclusiveness and win-win cooperation instead of a zero-sum game, and has promoted the healthy development of a new type of international relations.

\section{Challenges Ahead}

Any pioneering work is expected to encounter challenges and risks. The "16+1 Cooperation" Initiative is not an exception. Firstly, decline in economies and trade has created serious challenges for "16+1 Cooperation".

The "16+1 Cooperation" framework has always been committed to promoting bilateral trade and investment to reach a new high, but this objective seems difficult to fulfill due to the global and domestic uncertainty faced by "16+1" member states. According to foreign trade statistics provided by the Ministry of Commerce of China, from 2012 to 2014, most CEECs' trade with China fluctuated and showed a general downward trend, except a few CEECs like Poland, Bulgaria, Bosnia and Herzegovina, Montenegro, etc. By 2015, trade between China and most CEECs (not including Macedonia) declined, and quite dramatically. This downward trend has to do with China's reforms, attempting to stabilize economic growth, and adjusting its economic structure. The decrease is also related to the increasing competition in export markets due to the growing cost of raw materials and labor forces inside China. The capabilities of imports and exports of CEECs, on the other hand, are also negatively affected by the global economic and financial crisis. Besides, the impacts of larger China-EU relations on China-CEECs cooperation 
cannot be ignored, as the sustainable economic development of China and CEECs was undermined by the EU Anti-dumping and Countervailing investigation. It is also worth noting that China's trade surplus has caused concerns for some CEECs. For instance, Polish and Czech media often suspect Chinese enterprises of receiving illegal state subsidies and thus causing the trade deficit of their countries.

Secondly, the ever-worsening regional security has posed new challenges for the "16+1 Cooperation". The "16+1 Cooperation" framework has the disadvantage of a single function, as it only deals with business and does not involve politics. The security situation of the CEE region has been constantly challenged by the Ukraine crisis, refugee crisis, terrorism and tensions between Russia and EU. The CEECs bordering the Baltic Sea and the Black Sea are located at the forefront of the Russia-America and Russia-EU conflicts. As a result, the ways of dealing with all kinds of potential security threats are regarded as priority tasks by those countries. The "16+1 Cooperation" mechanism has indirectly played a role in resolving those crises since the necessity of cooperation with China in political and security realms has been underlined by CEECs many times. When the Ukraine crisis broke out, Poland insisted on calling for each party to resist Russia's "invasion" and acting in line with the EU's sanctions against Russia, but China seemed not to attach importance to it.

Thirdly, the all-round synergy of development strategies between China and CEECs faces many difficulties. China and CEECs have different understandings of national development. Countries adopting election politics focus more on employment, welfare and the sustainability of democratic governance. In contrast, China interprets development as the rise of economic competitiveness and the integration of economic resources on a global scale. The Chinese vision of "pursuing growth" is not in accord with CEECs' goal for stability. So far, the synergy of development strategies and initiatives emphasized by China has not produced tangible and fruitful results. It needs time, skills and experiences to nurture pragmatic cooperation. The differences in state regimes, thinking and behavioral patterns between China and CEECs have also caused difficulties in synergizing development strategies and initiatives. Apart from that, governmental instability, frequent elections and leadership transition of some CEECs has also undermined the effectiveness of China-CEECs cooperation. 
Lastly, while enhancing "16+1 Cooperation", China needs to wisely and properly handle its relationship with regional stakeholders. The CEE region is largely influenced by great powers. For instance, the EU maintains a strong economic and regulatory presence while the US continues its military presence in the region (through the NATO security framework). Moreover, CEECs are traditionally regarded by Germany as its key partners. Russia is also a key stakeholder in the CEE region. Under such a situation, how to properly handle relations with those big powers and organizations while developing ties with the 16 CEECs becomes a tricky issue for China. While the EU is not as suspicious of " $16+1$ Cooperation" as it used to be, its regulations still pose many difficulties for "16+1 Cooperation". Besides, the representatives of EU institutions have emphasized on many occasions that "16+1 Cooperation" needs to be more transparent. Only in that way can the China-EU cooperation progress. Although Germany, Russia and the US have not showed a clear position towards "16+1 Cooperation", their influence upon it is undoubtedly significant. Hence, much effort is needed to explore ways of expanding win-win cooperation with more stakeholders.

\section{Policy suggestions}

I will present four policy recommendations. (1) To actively create conditions and promote policy communication. Firstly, to focus on cooperation between various frameworks and platforms and achieve mutual agreements better policy communication is needed. The "16+1 Cooperation" framework is only a supplement to China-EU cooperation; hence its function is relatively limited. This is especially true in the early stages of development. Moreover, the topics under discussion cannot be increased without restrictions in every important field, especially in the political fields involving security. To maintain the vitality of cooperation, strategic cooperation must be promoted and in this regard, "16+1 Cooperation" and the Belt and Road Initiative have achieved something. Regarding the security issues faced by the CEECs, they can be solved within the framework of the UN, or within the EU and related sub-regional frameworks or regional security frameworks (such as the Organisation 
for Security and Cooperation in Europe). China can strengthen connectivity among various platforms or mechanisms.

Secondly, furthering open platforms would also enhance policy communication. The Belt and Road Initiative undoubtedly provides "16+1 Cooperation" with a wide platform and development space. Thus, in the future it is necessary to tap into the potential of local cooperation and third-party cooperation. It is essential to attract more stakeholders to become part of the initiative, to further open the observer system, to attract the EU and its Member States, international financial institutions and international organisations to taking part and to create greater energy for the platform. The EU is an inevitable influencing factor in " $16+1$ Cooperation", and the promotion of ChinaEU connectivity can be achieved through this third party. Meanwhile, China should actively promote prominent EU Member States, such as Germany and France, to be third parties in the China-CEECs cooperation.

A third way to increase policy communication in " $16+1$ Cooperation" is to strengthen the knowledge of relevant laws and regulations of the EU amongst Chinese policy makers. The CEECs have fully connected with the EU in the laws of various fields (even CEECs without EU membership), therefore, it is a necessary condition to know the EU's relevant laws for the promotion of " $16+1$ Cooperation". Meanwhile, the successful experiences of business management in the CEECs, such as Huawei, should be studied in order to know the invisible regulatory barriers for investment in CEECs.

(2) To develop even greater China-CEECs cooperation, to actively promote smooth trade flows and push forward infrastructure connectivity. China should: strengthen the promotion of exemplary engineering; create new highlights of China-CEECs cooperation; provide clearly the model of cooperation between the Belt and Road and industrial cooperation; complete construction of the HungarySerbia Railway within two years; actively build the China-Europe landsea Express Line; have successful cooperation towards the ports of the three seas and to accelerate connectivity amongst them. 
In the process of "going global", it should be established that enterprises are pioneers and pacesetters. Enterprises need to focus on communication with various countries in the fields of culture, education, etc. Based on the principal status of overseas investment, enterprises should work by international rules and market rules, focus on the establishment of international social accountability of Chinese enterprises, know in-depth local economic and social development demands, support increasing local employment, emphasise a cooperative spirit with openness, inclusiveness and mutual benefits, and remove the misgivings of CEECs.

(3) Based on a long-term strategy, to improve the financial support tools of bilateral cooperation. Effective integration of various financial tools is necessary to form lasting and steady financial support, focusing on the financing demands of CEECs. This can be achieved by actively discussing the establishment of a "16+1" investment bank and supporting the establishment of regional and multilateral international financial companies. Such a "16+1" financial company, actively learning from the experiences of international financial institutions in the CEECs, insisting on market-orientation and providing financial guarantees for bilateral cooperation.

(4) To strengthen publicity, to insist on an "enterprises-first" strategy and to promote people-to-people connectivity. China needs to advocate the positive ideas of the "Belt and Road" initiative and " $16+1$ Cooperation", to enhance mutual trust, remove misgivings, and to expand the channels of cooperation. The process of publicity should be forwarded by China's enterprises and NGOs, with the Government's support and follow-up. It will be more acceptable to allow enterprises to give publicity, as they are better suited for influencing society and media. Enterprises always connect their own investment and "going global", with the political significance of the Belt and Road and "16+1 Cooperation". Therefore, enterprises can tell better "Chinese stories".

To increase funding for CEECs scientific and academic institutions, it would be important to establish joint centres for Chinese studies in CEECs, thus enhancing the understanding of CEE elites towards China. 


\section{A Bibliography}

People, 2016. Li Keqiang attended the 6th China - Central and Eastern European Economic and Trade Forum and delivered a keynote speech. People, [online] 6 November. Available at: http://politics. people.com.cn/n1/2016/1106/c1001-28837894.html.

Xinhuanet, 2013. Xinhuanet, [online] March. Available at: http://news. xinhuanet.com/politics/2013-03/24/c_124495576.htm.

Liu Zuokui (liuzk@cass.org.cn) is Professor, Senior Research Fellow and Director of the Department of Central and Eastern European Studies as well as the Director of the Secretariat Office of 16+1 Think Tanks Network, Chinese Academy of Social Sciences. He is also the Director of the Beijing Office of China-CEE Institute in Budapest. 